\title{
21世紀の材料戦略と日本金属学会の果たす役割 先進金属系耐熱材料
}

山口正 治*

\section{1. 現 状と展望}

ジェットエンジン, ガスタービンのタービン翼, タービン ディスク, 燃焼器等の高温・高応力で使用される $\mathrm{Fe}, \mathrm{Ni}, \mathrm{Co}$ 基超合金の素材, 半製品は精密鋳造品, 鍛造品, 板 ·棒類に 大別されるが，いずれの国内生産高(例 : 精密鋳造品で年間 約500億円）も鉄鋼に比較して極めて少なく欧米に大きく遅 れをとっている.これは欧米政府が，これら超合金，特に $\mathrm{Ni}$ 基超合金を防衛戦略上の重要材料と位置づけ, 常に研究 開発を先導し，その成果を民間技術に活用する産業育成政策 をとり続けたからである(1).

今後我国の戦略的基幹産業として, 高効率発電システム, 航空宇宙, 自動車等の産業分野の国際競争力を増強するため には，超合金のみならず TiAl 基軽量耐熱合金，超耐熱合金 等の新耐熱材料分野に拈ける技術力をも飛躍的に向上させる ことが不可欠である.これら耐熱材料の性能は各種熱機関の 効率を決定する重要な要素であり,ひいては地球温暖化問題 に直結する炭酸ガス排出量にも大きく影響するからである. 幸いこれまでの国家プロジェクトを通して, 我国の耐熱材料 に関する技術と知的基盤は着々と整備 · 蓄積され, いくつか の材料の部材単体の試作レベルでは国際水準を凌駕するもの が出現している. しかし, 残念ながらこれらが広く実用され るには至っていない. 発電, 航空宇宙, 自動車産業等の産業 分野でこれらの基礎技術を実用化できれば，我国が金属系耐 熱材料分野で世界の主導権を握り得る素地は十分にある(1).

\section{2. 関連技術の現状と課題}

\section{（1） Ni 基超合金}

鍛造合金 超高温高効率ガスタービンのタービン翼および タービンディスク等に使用される超合金には耐熱性が極限ま で要求される，厳密な合金組成のコントロールと介在物の原 因となる微量元素の徹底的除去が不可欠である. 現在, イン ゴットメイキングはVIM/ESR の Double melt から VIM/ ESR/VAR の triple melt へ移行する傾向にあり, さらに高 い清浄度を目指してプラズマもしくは電子ビームによるコー
ルドハース再溶解も提案されている.このように, 大型超合 金インゴットの高性能溶解設備と溶製技術の確立が必要であ $ろ^{(1)}$.

航空機用エンジン重量のかなりの部分を占めるディスクや タービンヶース等の大型構造部品には, 欧米で開発された INCONEL718, WASPALOY, Rene 95, U720 等鍛造合金が 用いられている. 高疲労強度, 高勒性が要求されるこれら鍛 造合金の研究は，エンジンを軽量高性能化するための主要な テーマの一つである，材料特性のばらつきの少ない信頼性の ある材料を得るための研究として, 鍛造シミュレーション技 術とそれを支える材料特性，特に使用環境下での長時間使用 に関する材料特性データベースの蓄積が必要である。しか し，我国には，ディスク等の鍛造に用いられる大型鍛造プレ スがなく(米国には 5 万トンプレスが 2 基ある), 生産量も 伸びず関連研究も育っていない，この現状を打開する必要が ある(1).

鋳造合金 鋳造合金では, タービンの心臓部ともい方る高 温高圧部のタービン翼用合金が重要である. 鍛造合金から普 通鋳造合金, 一方向凝固合金, 単結晶合金へと開発が進み, 単結晶合金も, 初期の第 1 世代合金加 $5, \operatorname{Re} 3$ mass $\%$ 程 度含む第 2 世代合金, さらにRe 代合金へ移行し，いまや $\mathrm{Ru}$ 等貴金属を含む第 4 世代合金の 開発が行われている. 現在, 第 3 世代の単結晶合金 CMSX10 と Rene N6 がそれぞれロールスロイスと GE 社の最新型 ジェットェンジンに実用化されている. 発電用ガスタービン では，大型翼の鋳造性など製造性の制約からいまだ一方向凝 固合金が主流であるが，蒸気冷却など新しい冷却システムの 導入に対応して，第 2 世代の単結晶合金である CMSX-4 や Rene N5 等の導入が検討されている. 国内では， Reを1.52.5 mass\%に抑元良好な鋳造性を保らながら高温強度や異結 晶許容性を高めた単結晶合金や，Crを 12 mass\%程度含み 耐高温腐食性を確保した大型単結晶翼用合金など, 独自の新 合金が開発されている(1)(2).

ガスタービン翼はロストワックス精密鋳造法で製造され る. 航空ェンジン用の翼 $(\sim 150 \mathrm{~mm})$ に比べ, 発電用大型ガ スタービン翼は全長 $250 \mathrm{~mm}$ 以上と著しく大型になるため,

* 京都大学教授; 大学院工学研究科材料工学専攻 (年606-8501 京都市左京区吉田本町)

Advanced High-temperature Metallic Materials; Masaharu Yamaguchi(Department of Materials Science and Engineering, Kyoto University)

Keywords: high temperature materials, nickel-base superalloy, intermetallic compounds, TiAl, coating, refractory superalloys, niobium-base alloys

2001年 1 月 15 日受理 
完全な単結晶翼の製造には高度な一方向凝固技術を要する. 現在大型単結晶翼の製造可能なメーカーは米国の Howmet 社や PCC 社等数社に限られ，大型単結晶翼の量産化技術は 未だ開発段階にある．超合金の分野に拈ける未開拓領域の 1 つである(1).

コーティング ガスタービンの熱効率を上げるため，燃焼 ガス温度は常に上昇する傾向にあり, 動・静翼, 燃焼器等の 耐熱性を上げるため, 基材の腐食・酸化等を防止する高温耐 食・耐酸化コーティングや基材のメタル温度の低減を図る遮 熱コーティング(TBC)が行われる. 前者は, 0.1-0.2 mm 厚 の $\operatorname{MCrAlY}(\mathrm{M}: \mathrm{Ni}, \mathrm{Co})$ 系合金のプラズマ溶射, 電子ビーム 蒸着あるいは高速フレーム溶射による基材表面コーティン グ，後者は，この耐食耐酸化コーティング(ボンドュート)上 に, プラズマ溶射あるいは電子ビーム蒸着によってなされる 熱伝導率の小さい $\mathrm{ZrO}_{2}-\mathrm{Y}_{2} \mathrm{O}_{3}$ 系セラミックス $(0.2-0.5 \mathrm{~mm}$ 厚) コーティングである. TBC の長寿命化と信頼性向上のた めに, 熱応力低減のためのセラミックス組織(気孔, 微細ク ラック等) とボンドコート/遮熱セラミックス界面状態の最適 化に関する研究が求められている(1).

\section{（2） Ni 基超合金の耐熱限界を超える耐熱合金}

高融点超合金 $\mathrm{Ni}\left(\right.$ 融点 $\left.1455^{\circ} \mathrm{C}\right)$ をベースとして用いる限 り超合金の飛躍的な耐熱性向上は困難である。そこで, ベー スメタルに Ni 以外の高融点金属を用いて Ni 基超合金と同 じミクロ組織を再現した高融点超合金が開発されている。た とえば $\operatorname{Ir}\left(\right.$ 融点 $\left.2447^{\circ} \mathrm{C}\right)$ をべースとして用いることにより 200-300 MPa $/ 1800^{\circ} \mathrm{C}$ の強度を発揮し, 耐酸化性の点でも従 来の高融点金属・合金を大幅に越えた合金が得られている. 合金の比重, 価格, 適合するニーズの有無が問題であるが, 我国独自の合金である(1)(3).

$\mathrm{Nb}$ 基高融点合金 $2000^{\circ} \mathrm{C}$ 以上の融点をもつ高融点金属の 中でも, 室温延性と $\mathrm{Ni}$ よりさい密度をもつ $\mathrm{Nb}$ は高温材 料として魅力的である. この $\mathrm{Nb}$ をベースに， $1500^{\circ} \mathrm{C}$ 以上の 高温で冷却なしに使用できる高融点合金の開発が行われてい る. 高温強度, 耐クリープ性, 勒性に限れば, $\mathrm{Nb}-\mathrm{Mo}(30$ at $\%$ 以下) $-\mathrm{W}$ (20 at \%以下) 合金，さらに $\operatorname{Ir}(3 \mathrm{at} \%$ 以下)を添 加した合金, シリサイド相による析出強化合金 (Nb-20Mo22Ti-18Si 合金) 等優れた特性を示す合金が見出されてい る(1)(4). しかし，Nb 基合金の場合，耐酸化性が最大の問題 である、実用に耐え得る耐酸化性を有する合金(コーティン グ用合金も含む)が開発されれば画期的である.

\section{（3）軽量耐熱合金}

$\mathrm{TiAl}$ 基合金が新軽量耐熱材料として最も期待され，かつ 広く研究されている(5). 比強度では, $\mathrm{Ni}$ 基スーパーアロイ に匹敵し，比剛性ではそれを逵駕する(6). 遠心力のかかる回 転翼の最大周速は比強度の平方根に比例するら光, 軽量翼汪 ど起動から運転回転数に達する時間が短くなるなど, 回転翼 として有利な特性を備えている. 米国 GE 社で航空機エンジ ン用低王タービン翼への応用が試みられ, 技術的問題はほほ注 解決されたと報告されているが, 実際のエンジンへの搭載 は, 国際的な航空機マーケットの動向に依存するところが大 きいと言われている.航空機エンジン関係以外では, 1999 年ついに我国の重工メーカーによって，市販乗用車ターボチ
ャージャーのローター翼への本格的応用が達成された ${ }^{(7)}$. 現 在, 軽量性, 高比強度, 高比剛性を生かしたさらに新しい用 途への応用が試みられている.

$\mathrm{TiAl}$ 基合金ターボチャージャーローター翼の実用化成功 のニュースは, この分野の研究・開発にかかわる内外の研究 者に強烈なインパクトを与えた，我国の TiAl 基合金に関す る基礎研究のレベルが国際的最先端にあることは, 国内外の 広く認めるところである. TiAl 基合金は，いずれ軽量高温 材料分野の基幹材料となるであろら。この時, TiAl 基合金 の開発，製造，応用技術に関する de facto standard を我国 が握っていることが重要である.

\section{3. まとめ-今後の戦略}

現在稼動中の火力発電設備の平均熱効率は約 $40 \%$ であり, 最新の $1500^{\circ} \mathrm{C}$ 級ガスタービンを用いたコンバインドプラン 卜の熱効率は $53 \%$ と言われている。さらにタービン入口ガ ス温度 $1700^{\circ} \mathrm{C}$, 熱効率 $65 \%$ の高効率ガスタービン用耐熱材 料の開発が国家プロジェクトとして進められている.今後, 単に材料開発プロジェクトではなく，ガスタービンシステ ム, 航空機エンジン等を全体として開発実証する大型プロジ ェクトを立ち上げ，その中に材料に関わる国産技術を組み込 み使用実績を積み重ねることが，耐熱材料の分野で国際競争 力を確保していく上で重要である. 同時に, 耐熱材料分野で 新しく芽生兄つつある合金に対する先行投資(基礎・開発基 礎研究)は続けなければならない。豊かな土壤なくして豊か な稔りはあり得ない。

耐熱材料の研究開発には多大の時間を要する. しかも耐熱 温度の向上とそれによる熱効率上昇を数值で表現すれば一見 非常に小さなものに見党る。しかし, 発電等巨大システムが 背後にあって，わずかな熱効率の向上が，国全体でみれば巨 大な省ェネルギー, 環境保全効果をもたらすことを忘れるべ きではない(1).

平成 11 年度長期エネルギー技術戦略等に関する調査「産 業技術戦略策定基盤調查(分野別技術戦略〈耐熱材料技術分 野〉)」報告書の第 3 章先進金属系耐熱材料分野をもとに, 本稿をまとめた、本章の執筆に参加された先進金属系耐熱材 料ワーキンググループの委員全員が本稿の本来の著者である ことを記して，委員諸氏に深く感謝する.

\section{文献}

(1) 平成11年度長期エネルギー技術戦略等に関する調査「産業技 術戦略策定基盤調査（分野別技術戦略〈耐熱材料技術分野〉)」 報告書, 2000 年 2 月，株式会社超高温材料研究所.

（2）原田広史：日本ガスタービン学会誌, $28(2000), 278$.

( 3 ) Y. Yamabe-Mitarai, Y. Ro, T. Maruko and H. Harada: Metall. Mater. Trans. A, 29(1998), 537.

（4）重要地域技術研究開発制度「高融点金属系部材の高度加工技 術」(高効率発電用部材創製技術開発)成果報告書, 1999年.

( 5 ) M. Yamaguchi, H. Inui and K. Ito: Acta Mater., 48(2000), 307.

(6) C. M. Austin and T. J. Kelly: Structural Intermetallics, Ed., R. Darolia, J. J. Lewandowski, C. T. Liu, P. Martin, D. B. Miracle and M. V. Nathal, TMS, (1993), p. 143.

( 7 ) T. Tetsui: Current Opinion in Solid State \& Materials Science, 4(1999), 243. 